\title{
The Link Between Open Performance Review and Appraisal System and Other Human Resource Systems in Tanzania: Insights from IDC
}

\author{
Ausi nchimbi \\ Tanzania Public Service College, PO Box 1534, Singida, Tanzania
}

\begin{abstract}
This study intended to evaluate whether Open Performance Review and Appraisal System (OPRAS) as a tool of managing performance in Tanzania Public Service as currently used has been linked with other Human Resource systems. The study employed a cross-sectional research design. A sample of 80 respondents was used. Data was collected through questionnaires and interviews. The data collected were analyzed and processed through the use of SPSS computer software and descriptive statistics such as frequencies, percentages and tables were presented. The findings suggest that majority of participants reported that OPRAS as currently used in Iramba District Council (IDC) has not been linked with other human resource systems specifically training, career development, rewards and promotion. Thus, within the limitations of the study, it is concluded that Performance management system is not linked with other HR systems in Tanzanian Public Service. Thus hindering the intended intention of introducing OPRAS in Tanzanian Public service which are adoption and nurturing of the performance management culture in public service.
\end{abstract}

Keywords: Human Resource Management, Performance Management, Public Service and OPRAS

DOI: $10.7176 / \mathrm{EJBM} / 11-8-13$

Publication date:March $31^{\text {st }} 2019$

\section{Introduction}

1.1 Background of the study

Performance management systems are amongst the most important Human Resource practices and also continue to be the subject of interest and importance to Human resource subject both in theory and practice. Performance management refers to an approach that involves creating a shared vision of purpose and aims of the organization, helping each individual employee understand and recognize their part in contributing to them, and in so doing manage an enhance the performance of both the individual and the organization (Fletcher, 2011). Performance management as a concept is increasing gaining impetus in the public sector as in the business. (Pillay and Subban, 2007:55) viewed performance management in the public sector as a strategic approach to the management of Public resources and involves the pursuit for efficiency and effectiveness in Public service delivery.

The pressure to maximize results and quality in public service in most countries in the World has resulted to the adoption of New Public Management principles which bear a resemblance to many management techniques from the private sector. NPM come under the wave of Public sector reforms which has spread throughout the World in which performance management is an overarching focus. Thus it has been a central concern of elected officials, Public administrators and citizens for decades (Olufemi, 2009) He further asserted that managing performance has been one of the key drivers in the reform of the public sector in recent years and one of the central planks of what he called "reinventing government movement".

Tanzania like other countries in the World also has undertaken considerable reforms in managing public sector in the shape of new Public management by introduction of market type management practices in to the public sector with the aim of improving quality of public service. Thus there has been a significant improvement in the use of performance management systems in the Tanzania Public service. In fact every public organization is required to introduce performance management system so as to improve efficiency and effectiveness of its service delivery and to ensure that the value for money is achieved (Bana, 2009; Sulle, 2014; Rugumyamheto, 2005). Public service management and employment Policy of 1999 as revised in 2008 and the Public service Act No 8 of 2002 are the key instruments that facilitated the institutionalization of performance management system in the Tanzanian Public Service.

A number of processes, tools and mechanisms were introduced. The specific tools include strategic and operational planning, client service charters, service delivery surveys, self-assessment programs, performance budgeting, the introduction of Open Performance Review and Appraisal System (henceforth OPRAS) and comprehensive monitoring and evaluation system. (Bana, 2005) For the purpose of this study only OPRAS will be assessed.

OPRAS was introduced in Tanzania Public Service in the year of 2004. The tool aligns the objectives of the individual officer with that of the department to the entire objectives of the organization; it is used in all public organizations. Public service legislation made OPRAS as a mandatory to all MDAs. This paper intends to establish 
to what extent does OPRAS as a tool of managing performance in Tanzania Public service as currently used has been linked with other HR systems specifically rewards and employee's training and development.

\subsection{Statement of the problem}

The role of public service as a strong army of the government as well as the engine for social economic and technological advancement of any nation is widely acknowledged. The UN's Report (2005) concluded that 'No matter how organized and constitutional government is, it would not get very far in the absence of Public administration system capable of translating its broad political intention, enforcing its laws and delivering services needed by the people. Without professionally competent public administration the state cannot count on making those things happen in which it want to see happen or on pre-empting undesirable developments" (page 12)

Central to the realization of nation's goals and objectives public servants plays a crucial role and therefore their number, quality and their effectiveness makes the deference in realization of nation's goals. To achieve this there is no doubt that performance management in the public service is a center of importance. The overall of performance management should be to develop the capacity of employees so that the performance of every individual can be improved (Pareek and Rao. 2006:31) For performance management to be effective it should not be limited in measuring outcomes and output but it should serve as a mechanism to guide the direction of policy implementation and ensuring that it has been integrated with other HR systems in order to be coherent as a whole and make a meaningfully contribution to the public service efficiency and effectiveness. However policy and legal frameworks calls for integration between OPRAS and other HR systems there is a growing doubt that OPRAS as currently practiced is not aligned with other HR systems. It is through this realization that this study sought to examine the integration between OPRAS and other HR systems specifically reward and employee's training and development in Tanzanian Public Service. It contributes to the empirical analysis of the link between performance management and other HR systems in the public sector which remains underdeveloped empirically.

\subsection{Objectives of the study}

The main objective of this study is to examine the link between OPRAS and other HR systems in Tanzania Public Service. Specifically the study aim to examine to what extent does OPRAS has been linked with the Rewards and employee's training and development at Iramba District Council.

\subsection{Literature review}

\subsection{Theoretical Literature review}

\subsubsection{Expectancy theory}

Expectancy theory states that motivation will be high when people know what they have to do to get a reward, expect that they will be able to get the reward and expect that the reward will be worthwhile. The theory was formulated by Vroom (1964 in Armstrong, 2009 ). According to this theory motivation is only likely when a clearly perceived and usable relationship exists between performance and outcome, and the outcome is seen as a means of satisfying needs. This explains why extrinsic financial motivation - for example, an incentive or bonus scheme - works only if the link between effort and reward is clear and the value of the reward is worth the effort. This theory was developed by Porter and Lawler (1968 in Armstrong, 2009) into a model that follows Vroom's ideas by suggesting that there are two factors determining the effort people put into their jobs: first the value of the rewards to individuals and second the probability that rewards depend on effort, as perceived by individuals - in other words, their expectations about the relationships between effort and reward. Thus the greater the value of a set of rewards and the higher the probability that receiving each of these rewards depends upon effort, the greater the effort that will be expended in a given situation; But, as Porter and Lawler emphasize, mere effort is not enough. It has to be effective effort if it is to produce the desired performance.

This theory is applicable in this study because it helps to explain the relationship that exists between performance appraisals and Compensation management.

\subsubsection{Equity Theory}

Equity theory (Adams, 1965 in Armstrong, 2009) is concerned with the perceptions people have about how they are being treated as compared with others. To be dealt with equity is to be treated fairly in comparison with another group of people (a reference group) or a relevant other person. Equity involves feelings and perceptions and it is always a comparative process. It is not synonymous with equality, which means treating everyone the same, since this would be inequitable if they deserve to be treated differently. Equity theory states, in effect, that people will be better motivated if they are treated equitably and they will lack motivation if they are treated inequitably. It explains only one aspect of the processes of motivation and job satisfaction, although it may be significant in terms of morale. There are two forms of equity: distributive equity, which is concerned with the fairness with which people feel they are rewarded in accordance with their contribution and in comparison with others; and procedural equity, which is concerned with the perceptions employees have about the fairness with which company procedures in such areas as performance appraisal, promotion and discipline are being operated. Armstrong (2009) 
Equity theory can be applied in understanding the link between performance management systems and other HR functions ensuring that employees are compensated based on their qualifications and experience. Equalization in compensation will tend to motivate employees to perform and feel appreciated (Chua, 2009).

\subsection{The link between performance and other Human Resource Functions}

Performance management which is most concerned with the evaluation of an individual's job strengths and weaknesses is not carried out in isolation. Rather the process should be integrated and cohere with other human resources' functions and processes such as human resources planning, promotion, training and development and rewards management. PAs are of great value to any organization; however, its value will depend on how well the process is integrated with other human resources' functions and processes.

\subsubsection{Performance Appraisals and Human Resource Planning}

Human resource planning is used to estimate the future need of human capital that the firm needs in order to achieve its goals by analyzing current job occupation, turnover, transfers, promotions and retirements (Hasbroeket al., 2008:275). Because managers and supervisors must take decisions concerning promotions, demotions, transfers and layoffs, past PA results are of great importance since they will help to determine which employee is most deserving of a promotion or other desirable job changes (Gomes-Mejaet al., 2001:226). Thus, through performance evaluation results, the organization is able to plan for future personnel needs for example which employee will need training or which skill the organization is lacking so as to determine if external recruitment is a solution.

\subsubsection{Performance management and Promotions}

If promotions are not well administered they will likely lower morale and high turnover. This can be the order of days in an organization which will eventually reduce productivity and increase unnecessary costs. Performance evaluation can be used to increase and improve employees' performance. An effective PA will also improve employees' motivation. Thus, when conducting performance evaluations for promotion purposes subjectivity such as halo effect and central tendency should be strictly avoided so that any outcome of the appraisals will be perceived as fair by all employees who will be expecting promotion

\subsubsection{Performance Appraisals and Rewards Management}

If the organization decides to use metric pay system, which is based on PA's results then it follows that appraisals must be done and done very well. Even if PA's results are not used for merit pay purposes, there is a good reason to believe that PAs should be done. The most common decisions based on evaluative objectives concerning compensation include merit incentives, employees' bonuses and other increases in pay. Thus, the term merit review or merit evaluation can be found in an organization using PAs to determine pay increase (Grobleret al., 2001:265). Employee's rewards is said to be the sole most important cost in most organizations (Gomez et al, 2012; Dessler, 2008; \&Mwangi, 2014) There for is not bad to conclude that the effectiveness with which rewards are allocated can make a significant different in gaining or loosing competitive edge. According to Dessler, (2008) developing a good employee's rewards plan is important for any organization and employees. He further noted that improperly designed compensation plan may results to wage rate that is too high hence unnecessary wage bills and expenses; while paying less may results to lack of motivation to employees and labor turnover. At the same time internally inequitable compensation rates reduce employee's morale and motivation and causes endless complains from the employees. Therefore determination of compensation packages is a very important aspect in compensation management. Nelson \& Spitzer, (2003) argued that the most important aspect of any compensation plan is the relationship between it and performance. Compensation plan should be integrated in order to create a meaningfully whole. For this reason performance appraisal is an integral part in the design and the implementation of effective compensation plan in an organization. The design and the administration of any compensation plan should be cost effective and aim to help organization to attract, motivate and retain qualified and competent employees required by the organization to achieve its strategic objectives. Decenzo et al, 2007; Armstrong, (2008)

Dessler (2008) pointed out that there are several factors that should be considered if organization wants to design an effective and efficiency compensation plan. These factors include; legal consideration, union influences, company policies, organization strategic objectives and internal and external equity.

\subsubsection{Performance Appraisals and Human Resource Training and Development}

Employees' PAs are particularly appropriate for identifying individual training and development needs. After all, an appraisal is proposed to determine how well an individual is performing his or her job. Performance deficiencies can be stemming from the lack of knowledge or skills. This can be appropriately used to identify traditional training needs. While proficiencies in performance are traditionally used to plan employees' educational activities leading to promotion or other future career moves for individuals.

Carellet al. (2001:265) posited that the results of PAs influence decisions about training and development of employees. For them, below average evaluation may signal areas of employee's behavior that may be strengthened through training. Off course it has been argued that not all performance deficiencies may be overcame by training and development. It is therefore the role of managers and supervisors to distinguish problems resulting from the 
lack of the critical skills or ability from those caused by low morale or some form of job dissatisfaction.

\subsection{Conceptual framework}

For better understanding of the subject matter in question system approach was chosen as a conceptual framework. System approach asserts that in order to understand fully the operation of an entity, the entity must be viewed as a system. This requires the understanding of its parts. The system is a set of interrelated but separate parts working towards a common goal or purpose. The arrangement must be orderly and there must be proper communication facilitating interaction between the elements and finally this interaction should lead in achieving of common goals. System approach to management views the organization as a unified, purposeful system composed of interrelated parts. Therefore a system oriented manager would make decisions only after they have identified impact of those decisions on all other departments and the entire organizations processes, programs and procedures. Therefore a well-established performance management system can be framed in a way that makes a clear link to other Human resource management functions. A well-established performance management assumes casual links between different functions and enables underperformance in one or more aspect of the process to be managed to ensure optimum functioning of the whole performance management system.

\subsection{Methodology}

\subsection{Research design}

To achieve its objectives a case study design was adopted. Aakeret al., (ibid) defined a case study as a comprehensive description and analysis of a single situation. In addition, the case study approach place emphasis on a fully contextual analysis of fewer events or conditions and their interactions (Cooper and Schindler, 2003). This study design was adopted because it brings the deeper sights and it enables the researcher to make a comprehensive inquiry into the nature of the phenomenon. Also, using this type of research design facilitates generalization to other cases not covered by this study and creates a base for replication of the study using large sample of cases. Moreover, case study designs allow various data collection methods to be employed such as interview and questionnaire so as to come up with the data required to answer the research objectives and thus validate the generalization at the end.

The study also used both qualitative and quantitative approaches. A qualitative research approach is a method used to find out how people feel or what people think about a particular subject or institution, where quantitative research design is based much on the measurements of quantity or amount (Kothari, 2004). Hence, quantitative research approach was used in calculating simple percentage and number of respondents. Therefore this is a mixed research design which use both qualitative and quantitative.

\subsection{Study Population, sample size and sampling technique}

The targeted population of this study was employees of Iramba District Council at its head office. The council has total number of 98 employees working at its head office. The Questionnaires were distributed to all employees who were present in their offices at the time when survey was conducted. These comprised heads of departments, administrative and technical staffs in deferent departments. The study intended to have a clear picture by involving all kinds of employees. A random sampling technique was employed and employee's register was used as a study sampling frame. 90 questionnaires were distributed to respondents and 80 of them were collected this make the respondent rate to be $90 \%$.

\subsection{Research instruments}

Data were obtained through a set of questions that were drawn up to meet the objective of this study. As set of questions were designed in which the respondents were required to fill in the answers. Properly constructed questionnaire in English language was prepared and administered to respondents who were the employees of IDC. An interview was also used to collect qualitative data which could not be collected through questionnaires. Furthermore the study needed a deep explanation on some matters with relation to the research problem. 


\subsection{Results and Discussions}

Q 5 I believe OPRAS clearly separate performers from non-performers

Table 5.1

\begin{tabular}{lrrrr}
\multicolumn{1}{c}{ Choices } & Frequency & Percent & Valid Percent & Cumulative Percent \\
Highly dissatisfied & 13 & 16.3 & 16.3 & 16.3 \\
Dissatisfied & 23 & 28.8 & 28.8 & 45.0 \\
Neutral & 12 & 15.0 & 15.0 & 60.0 \\
Satisfied & 22 & 27.5 & 27.5 & 87.5 \\
Highly satisfied & 10 & 12.5 & 12.5 & 100.0 \\
Total & 80 & 100.0 & 100.0 & \\
\hline
\end{tabular}

\section{Source: Author's field survey (2018)}

On the first question respondents were asked about the effectiveness of OPRAS in separating performers and non-performers in IDC. As shown in table 5.1 results revealed that majority of respondents $45.1 \%$ were dissatisfied with the effectiveness of OPRAS in separating performers from non-performers also $15 \%$ of respondents were neutral while $40 \%$ of respondents were dissatisfied with the effectiveness of OPRAS as a tool of managing performance to effectively separate performers from non-performers. The results from interview also indicated that majority of participants doubted the capacity of OPRAS as currently used at IDC to separate performers from non-performers.

Q 6 Planning for my competence development is done during review process Table 5.2

\begin{tabular}{|l|l|r|r|r|r|}
\hline \multicolumn{2}{|c|}{ Choices } & Frequency & Percent & \multicolumn{1}{|c|}{ Valid Percent } & \multicolumn{1}{c|}{ Cumulative Percent } \\
\hline Highly dissatisfied & 10 & 12.5 & 12.5 & 12.5 \\
\hline Dissatisfied & 10 & 12.5 & 12.5 & 25.0 \\
\hline Neutral & 30 & 37.5 & 37.5 & 62.5 \\
\hline Satisfied & 22 & 27.5 & 27.5 & 90.0 \\
\hline Highly satisfied & 8 & 10.0 & 10.0 & 100.0 \\
\hline Total & 80 & 100.0 & 100.0 & \\
\hline
\end{tabular}

\section{Source: Author's field survey (2018)}

Table 5.2 shows that majority of respondents $37.5 \%$ were neutral about whether the planning for their competence development is done during review process. The same number of percent 37.5 showed positive satisfaction with the question that planning for competence development is done during review process; while $25 \%$ of respondents were dissatisfied with the statement that the planning for my competence development is done during review process. The results from interview indicated that majority of respondents were highly dissatisfied with this statement. Though $37.5 \%$ of respondents showed positive satisfaction about the integration between OPRAS and planning for competence development it is hard to conclude that there is integration because during interviews majority of respondents were in the view that planning for competence development is not done during review process.

Q7. My performance standards that are not currently met are identified as development areas for me Table 5.3

\begin{tabular}{|l|l|r|r|r|r|}
\hline \multicolumn{1}{|c|}{ Choices } & Frequency & \multicolumn{1}{c|}{ Percent } & Valid Percent & Cumulative Percent \\
\hline Highly dissatisfied & 18 & 22.5 & 22.5 & 22.5 \\
\hline Dissatisfied & 12 & 15.0 & 15.0 & 37.5 \\
\hline Neutral & 30 & 37.5 & 37.5 & 75.0 \\
\hline Satisfied & 13 & 16.3 & 16.3 & 100.0 \\
\hline Highly satisfied & 7 & 8.8 & 8.8 & 1.3 \\
\hline Total & 80 & 100.0 & 100.0 & \\
\hline
\end{tabular}

\section{Source: Author's field survey (2018)}

The results on this question indicate that majority of respondents $35.5 \%$ were dissatisfied with the statement while $35.5 \%$ were neutral and the remaining $23.1 \%$ of respondents were satisfied with the statement. The results on interview indicated that majority of respondents were dissatisfied with the statement. This is contrary with the literature which requires that performance review results should form a base for decisions relating to training and development. 
Q8. My performance data from OPRAS reviews are direct linked to incentives Table 5.4

\begin{tabular}{|l|l|r|r|r|r|}
\hline \multicolumn{1}{|c|}{ Choices } & Frequency & Percent & Valid Percent & Cumulative Percent \\
\hline Highly dissatisfied & 21 & 26.3 & 26.3 & 26.3 \\
\hline Dissatisfied & 26 & 32.5 & 32.5 & 58.8 \\
\hline Neutral & 12 & 15.0 & 15.0 & 73.8 \\
\hline Satisfied & 17 & 21.3 & 21.3 & 95.0 \\
\hline Highly satisfied & 4 & 5.0 & 5.0 & 100.0 \\
\hline Total & 80 & 100.0 & 100.0 & \\
\hline
\end{tabular}

\section{Source: Author's field survey (2018)}

In this question respondents were asked to provide their opinion whether OPRAS as a tool of managing performance has been linked with other rewards. Results shows that majority of the respondents $58.8 \%$ were not satisfied with the statement while $26.3 \%$ of respondents were satisfied and the remaining $15 \%$ were neutral. This result concurs with the results from the interview where majority of respondents were in the view that the results from performance review are not linked to employee's rewards which is contrary to what has been advocated in the management literature.

Q9. I believe my recent promotion was based from my performance data from previous performance results Table 5.5

\begin{tabular}{|l|l|r|r|r|r|}
\hline \multicolumn{1}{|c|}{ Choices } & Frequency & \multicolumn{1}{c|}{ Percent } & Valid Percent & Cumulative Percent \\
\hline Highly dissatisfied & 23 & 28.8 & 28.8 & 28.8 \\
\hline Dissatisfied & 16 & 20.0 & 20.0 & 48.8 \\
\hline Neutral & 11 & 13.8 & 13.8 & 62.5 \\
\hline Satisfied & 23 & 28.8 & 28.8 & 91.3 \\
\hline Highly satisfied & 7 & 8.8 & 8.8 & 100.0 \\
\hline Total & 80 & 100.0 & 100.0 & \\
\hline
\end{tabular}

Source: Author's field survey (2018)

The findings of this question indicated that majority of respondents $48.8 \%$ were satisfied with the statement while $37.6 \%$ were not satisfied and the remaining $13.8 \%$ were neither satisfied nor dissatisfied with the statement. Further analysis from interview indicated the same results that the decisions about promotions do not result from performance reviews data. This is also contrary to the management literature which requires the integration of rewards and performance management. (Armstrong, 2009) Therefore all decisions related to rewards and promotions among other things should be generated from performance reviews data.

This study doesn't detect any convincing evidence for the integration of OPRAS and other HR systems in IDC. Since majority of Respondents agree that OPRAS as currently practiced in IDC is not integrated with employee's training, development, rewards and promotions. These results are consistence with that of Msemo (2011) who reported that the feedback from OPRAS is not used especially in promotions, selection of best performers and capacity building. This was done without any reference to the information available from OPRAS feedback if an employee has weakness or not. Also, the best performers of the year in the organization was chosen based on the majority votes of employees and not on the feedback obtained from OPRAS. Besides, the study conducted by Mpanda (2015) revealed that despite the government efforts to introduce systematic procedures in conducting training, issues of Training needs assessment are neglected. This state of affairs has continuously led to the presence of trainings which do not reflect the needs of the job and organization in the public sectors.

The study conducted by Baraka (2015) also revealed the same results that the results of OPRAS exercise is not geared to help employees but rather used as a weapon by supervisors. The study further avow that majority of workers believe OPRAS results have no impact at all to their performance levels.

\section{5 .0 Conclusion, Recommendations, Policy Implications and Limitations of the study \\ 5.1 Conclusion}

The major finding that depict from this study is that however in its design the tool has been linked with other HR systems but as currently used at IDC the tool has not been linked with other HR systems specifically training and development, rewards and Promotions. This is contrary with its initial establishment target which requires that performance appraisals should, among other things, serve as a foundation for identification of the employee's training needs and also should act as a base for promotion decisions.

\subsection{Recommendations}

Study revealed that OPRAS as currently used at IDC is not integrated with other HR systems specifically training and development and Rewards and promotion as currently practiced at IDC. The study therefore offers the following recommendations to be considered by IDC for successfully implementation of OPRAS as a tool of 
managing performance that could result to improved employee's performance and the council in general.

Performance management tool like OPRAS should serve as a means to an end, hence should not become an end in itself. The decisions for training should emerge from the results of OPRAS reviews. This would enable employees to perceive OPRAS as a useful tool in their career development.

OPRAS also should provide a means to recognize and reward good performance as well as to manage underperformance. Recognition or reward for performance, including performance related pay (PRP), salary progression guided by performance or non-pay system should be used as positive reinforcements in order to enable employees buy into the imperatives of OPRAS.

\subsection{Policy Implications}

The findings of this study have revealed that the results of PAs are not used to determine training needs among employees. Also the performance data are not used to determine the pay rise and promotion among employees at IDC. The policy implication for this is that the government should make sure that OPRAS is linked with other HR systems. The current approach of strategic human resource management requires HR systems to operate as a unit. There should be horizontal integration of the individual HR systems in order to cohere and support each other rather than existing as isolated systems.

\subsection{Limitations}

Although the findings of the study found to be reliable due to the instrument used, the fact that a small sample size of the respondents (33) were involved and restricted to Iramba District Council the results limit the possibility of generalizing the findings to the entire Tanzania Public service. Future research on this subject could focus on extending the studies of this nature to a wide range of Public Organizations to include diverse respondents. However despite the aforementioned limitations the study findings bid a insightful contribution to the empirical analysis of the link between OPRAS and other HR systems in Tanzanian Public Service which remained underdeveloped empirically.

\section{References}

Aaker et al., (2002): Marketing Research (7th Ed), New Delhi, John Wiley

Armstrong M., (2000), Performance Management, Key Strategies and Practical Guidelines, Second Edition, UK, Kogan Page Limited.

Armstrong, M. (2009).A Handbook of Human resource management practice. 11th edition.Cambridge University Press.

Bana, B (2009) Performance Management in the Tanzania Public Service: A paper Presented at the Conference on Governance Excellence:' managing Human Potential' Held at Arusha International Conference Centre, United Republic of Tanzania, from $2^{\text {nd }}-4^{\text {th }}$ March 2009.

Baraka M (2015) The role of Performance Appraisal System on Individual workers performance in Public Organizations (Master thesis, Mzumbe University)

Baron, A. (2004) Managing Performance: Performance management in action. London: CIPD.

Bateson, M., Nettle, D., \& Roberts, G. (2006).Cues of being watched enhance cooperation in a real-world setting. Biology Letters, 2, 412-414

Beer, M \&Ruh, R.A (1976): Employee Growth Through Performance Management: Havard Business Review, pp. $59-66$

Brannen J, (2012) Mixing Methods: Qualitative and Quantitative Research. The University of Michigan, USA

Buchner, T.W (2007) Performance Management theory: A look from the Performer's Perspective with its Implications for HRD. Human Resource Development International, Vol. 10 ,Iss. 1,2007

Cleveland, J.N., Murphy, K.R., \& William, R.E. (1989). “Multiple Uses of Performance Appraisal: Prevalents and Correlates".Journal of applied Psychology.Vol. 74. No. 1, 130-135.

Cooper, D.R. and Schindler, P.S. (2003) Business Research Methods. 8th Edition, McGraw-Hill Irwin, Boston.

Davis, S., \& Albright, T. (2004).An investigation of the effect of balanced scorecard implementation on financial performance.Management accounting research, 15(2), 135-153.

DeNisi A S Pritchard R D (2006) Performance appraisal performance management and from AML 3031 at University of Florida.

Fletcher, C. and Williams, R. (1992) Performance Management in the UK: Organizational experience. London: IPM.

Gall et al. (1996).Educational Research: An Introduction. New York: Longman Publishers

Gall, D.M.,Borg,N.R., and Gall, J.P (1996). Educational Research: An Introduction. New York: Longman Publishers.

Gomez-Mejia, L. R., Nuñez-Nickel, M., \& Gutierrez, I., 2001. The Role of Family Ties in Agency Contracts. Academy of Management Journal, 44: 81-96. 
Guest, D. (1999) Human Resource Management_the workers verdict, Human Resource Management Journal, vol. 9(3), pp.5-25.

Guthrie, J and English, L (1997) Performance Information and Programme Evaluation in the Australian Public Sector; International Journal of Public Sector Management, 10(3), pp.154-164;

Hale, R.; Whitlam, P. 2000. Powering up performance management: An integrated approach to getting the best from your people. Brookfield, VT (USA): Gower. ISBN 056608189X

Hildebrand, R. (2007) 'Measuring and Managing Performance in Local Government: A Literature Review; Working Paper Series, University of Victoria.

Kombo\&Tromp. (2006) Methodology of Research in Social sciences. Delhi, Himalaya Publishing House International (P) LTD.

Kothari, (2004): Research Methodology-Methods and Techniques, New Age

Krishnaswami, O. (2002). Methodology of Research in Social Science. Delhi: Himalaya.

Macky,K.,\& Johnson, G. (2000).The strategic Management of Human Resources in New Zealand. Auckland, New Zealand: Irwin/McGraw-Hill

Mpanda I (2015) Effectiveness of Open Performance Review and Appraisal system in Identifying Training needs (Master Thesis, Mzumbe University)

Msemo, R (2011) The assessment of Effective Implementation OPRAS system in Public Service in Tanzania: Case study President's Office Public service Management (Master Thesis KDI school of Public Policy and Management

Ngumuo, S \& Wang, M (2015) Measuring Performance in Public Sector Organizations: Evidence from Local Government Authorities in Tanzania; European Journal of Business and Management. Volume, 7 No. 9, pp. 184-194

Panda, S (2011) Performance Management system: Issues and Challenges; Journal of Management Studies; Volume 36 No.3

Purcel, J et al (2003) Understanding People and Performance Link: Unlocking the Blackbox Research Report. London: CIPD

REPOA, (2008).Local Autonomy and Citizen Participation in Tanzania from a Local Government Reform Perspective, Dar es Salaam: MkukinaNyota Publishers.

Rugumyamheto, J. (2005) Performing the Public Service in Tanzania: A critical Prerequisite to Economic Growth, Health Creation and Poverty Reduction; Paper Presented at AAPAM annual Roundtable Conference, held at Mombasa, Kenya from $7^{\text {th }}-11^{\text {th }}$ March, 2005.

Saunders, M; Lewis, P and Thornhill, A. (2012). Research Methods for Busness Students. (6th, Ed.) Rotorito-Italy: Pearson Education Ltd.

Selden, S \& Sowa J,E. (2011) Performance Management and Appraisal in Human Service Organizations: Management and Staff Perspectives; Public Personnel Management Volume 40 No.3 Fall 2011

Songstad NG, Moland KM, Massay DA, Blystad A: Why do health workers in Tanzania prefer public sector employment?. BMC Health Serv Res. 2012, 12: 92-10.1186/1472-6963-12-92.

Stevers, B.P and Joyce,T. (2000), "Building a balanced performance management system" SAM Advanced Management Journal,Vol.8.

Sulle, A, (2014) The use of Performance Measurement Information in the Tanzania Public Sector: The case of National Housing Corporation: International Journal of Management Science and Business Research, Vol-3, Issue 7.

Tom C (2004), Performance Management and Public Sector Reform: The Norwegian Hospial Reform».

United Republic of Tanzania (1999).Public Service Management and Employment Policy, Dar es Salaam: POPSM

United Republic of Tanzania (2002) Public Service Act

United Republic of Tanzania (2003).Public Service Amendment Act of 2007, Dar es Salaam: Government Printer.

United Republic of Tanzania (2005).Public Service Reform Programme- Phase Two (PSRP II (2008-2012), Dar es Salaam: PO-PSM

URT (2004).Installation of performance Management systems in ministries and Independent Departments, Presidents office, Public Service Management, Tanzania.Unpublished paper.

URT.(2011) OPRAS Guideline

World Bank (2008) Implementation Completion and Results Report for a Public Service reform Project (IDA33000 IDA 3300AI: Dar es Salaam.

Yeasmin, S \&Rahman K, (2012). Triangulation Research Method as the Tool of Social Science Research.BUP journal, 1(1), 154-163.

Nelson B \& Spitzer D, (2003) The 1001 Rewards and Recognition field book: The complete Guide, Workman Publishing. New York

Gomez-Mejia, L. R., Nuñez-Nickel, M., \& Gutierrez, I., 2001. The Role of Family Ties in Agency Contracts. 
Academy of Management Journal, 44: 81-96.

Dessler, G. (2008). Human Resource Management. Upper Saddle River, NJ: Pearson/Prentice Hall.

David, A. Decenzo.\& Stephen, P. R. (2007). Fundamentals of Human Resource Management, John Wiley and Sons, Inc. 